\title{
Article
}

https://doi.org/10.11646/phytotaxa.297.2.2

\section{Speciation in the genera Anthericum and Chlorophytum (Asparagaceae) in Ethiopia-a molecular phylogenetic approach}

\author{
CHARLOTTE S. BJORÅ ${ }^{1 *}$, MARTE ELDEN ${ }^{2}$, INGER NORDAL ${ }^{2}$, ANNE K. BRYSTING ${ }^{3}$, TESFAYE AWAS ${ }^{4}$, \\ SEBSEBE DEMISSEW ${ }^{5} \&$ MIKA BENDIKSBY $^{1,6}$ \\ ${ }^{I}$ Natural History Museum, University of Oslo, P.O. Box 1172 Blindern, NO-0318 Oslo, Norway \\ ${ }^{2}$ Department of Biosciences, University of Oslo, P.O. Box 1066 Blindern, NO-0316 Oslo, Norway \\ ${ }^{3}$ Centre for Ecological and Evolutionary Synthesis, Department of Biosciences, University of Oslo, P.O. Box 1066 Blindern, NO-0316 \\ Oslo, Norway \\ ${ }^{4}$ Institute of Biodiversity Conservation, P.O. Box 30726, Addis Ababa, Ethiopia \\ ${ }^{5}$ National Herbarium, College of Natural Sciences, University of Addis Ababa, P.O. Box 3434, Addis Ababa, Ethiopia \\ ${ }^{6}$ NTNU University Museum, Norwegian University of Science and Technology, 7491 Trondheim, Norway \\ *Author for correspondence. Email: charlotte.bjora@nhm.uio.no
}

\begin{abstract}
Sister group relations of Ethiopian species of Anthericum and Chlorophytum and variation patterns in the C. gallabatense and $C$. comosum complexes were studied using molecular phylogenetic analyses, morphometrics, and scanning electron microscopy of seed surfaces. Results indicate that molecular data largely support previous morphological conclusions, and that speciation has occurred in Ethiopia at least three times in Anthericum and repeatedly within different subclades of Chlorophytum. Areas particularly rich in endemic species are the lowland area around Bale Mountains in SE Ethiopia and in the Beninshangul Gumuz regional state in W Ethiopia near the border to Sudan. A new species, Chlorophytum mamillatum Elden \& Nordal, is described, and the names $C$. tordense and C. tetraphyllum are re-instated.
\end{abstract}

Key words: Anthericaceae, endemism, Horn of Africa, sister group relations, taxonomy

\section{Introduction}

The family Anthericaceae was revised for the Flora of Ethiopia and Eritrea (FEE) by Nordal (1997); different representatives are shown in Fig. 1 A-I. In APG III (2009), Anthericaceae is sunk into a broadly-defined Asparagaceae. In FEE, three species of Anthericum Linnaeus (1753: 310) and 23 species of Chlorophytum Ker Gawler (1807: 1071) were recorded, of which two and eight, respectively, are endemic to the Horn of Africa, including NE Kenya (Fig. 2A). Furthermore, there is a Somalian endemic element of seven species of Chlorophytum (Nordal \& Thulin 1993; Thulin 1995; Nordal et al. 2001). Some unsolved problems in species delimitation were pointed out in the FEE, for example that "shade forms" of C. gallabatense Schweinfurth ex Baker (1876: 325) (Fig. 1H) might be confused with C. comosum (Thunberg 1794: 63) Jacques (1862: 345) because of the almost prostrate inflorescences in both. The two were, however, suggested to be distinguished on flower colour (greenish in the former and whitish in the latter) and on roots (lateral tubers in the former and subterminal tubers in the latter). This problem of species delimitation has so far not been solved.

Since 1997, the following three new endemic species of Chlorophytum have been described from Ethiopia: $C$. herrmannii Nordal \& Sebsebe (2005: 326), C. serpens Sebsebe \& Nordal (2005: 328), and C. pseudocaule Tesfaye \& Nordal (2007: 129) (Fig. 1E). Further, the endemic C. neghellense Cufodontis (1939: 311) (Fig 1B) was transferred to Anthericum as A. neghellense (Cufodontis) Bjorå \& Sebsebe (in Bjorå 2008: 122). In the current understanding of Anthericum, the genus consists of seven species, four of which are found in Ethiopia. Chlorophytum, on the other hand, includes around 180 species with 25 occurring in Ethiopia.

The genera Anthericum and Chlorophytum have recently been subjected to preliminary molecular phylogenetic investigations (Hoell 2005; Bjorå 2008; Elden 2010). Bjorå (2008) showed that specimens of C. comosum from southern Africa, where the type specimen was collected, did not group with "C. comosum" sensu Flora of Tropical East Africa (FTEA, Nordal et al. 1997). 
Our primary aims with the present paper are:

1. To investigate the phylogenetic sister group relations of the Ethiopian species of Anthericum and Chlorophytum to elucidate possible speciation patterns.

2. To assess the variation patterns in the C. gallabatense and C. comosum species complexes and establish if the so-called "shade form" of $C$. gallabatense mentioned in FFE should be recognized taxonomically.

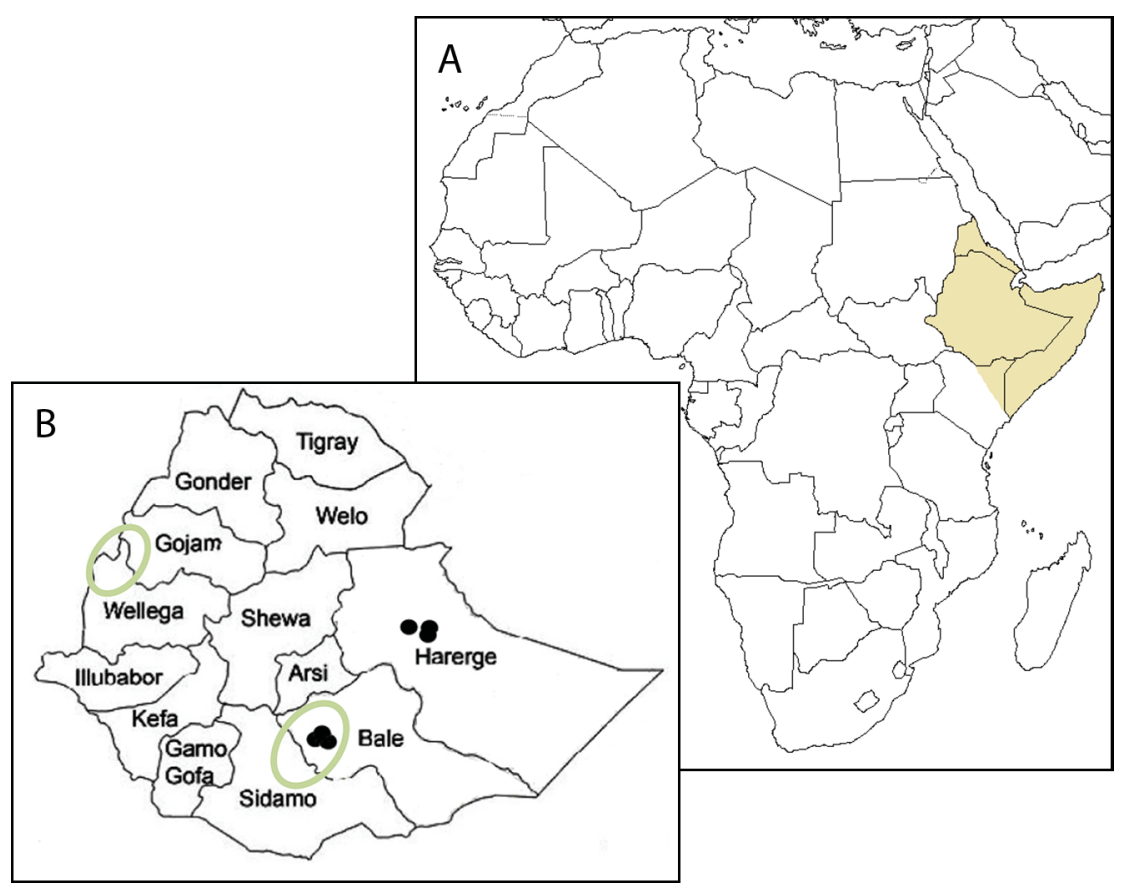

FIGURE 1. A. Map of Africa; Horn of Africa, including north-eastern Kenya, highlighted. B. Map of floristic regions in Ethiopia; dots displaying the distribution of Chlorophytum mamillatum ("shade form" of C. gallabatense in FFE). Green circles indicate the two main evolutionary hotspot areas of Chlorophytum.

\section{Materials and Methods}

\section{Plant material for molecular work}

Plant materials used in the present study are from herbarium specimens held at BRLU, ETH, K, O, and WAG, and from silica-dried leaf samples collected during field work in Ethiopia in 2007 (vouchers deposited at ETH). A total of 69 specimens (Table 1) were studied. Available specimens from Ethiopia were supplemented by specimens from other parts of Africa to attain a broader taxonomic and geographical context. Unfortunately, two relevant species, C. inconspicuum (Baker 1877: 71) Nordal (1993: 63) and C. bifolium Dammer (1905: 66), could not be included in the present study. Both species are very rare, and may have gone extinct. The species concepts followed herein are according to FTEA, FEE, and Flora Zambesiaca (Kativu et al. 2008). There is one discrepancy in these floras; Chlorophytum tordense Chiovenda (1916: 173) of FEE was reduced to C. affine Baker (1875: 160) var. curviscapum (Poellnitz 1942: 122) Hanid (1974: 588) in FTEA.

\section{DNA extraction, PCR amplification and DNA sequencing}

Total genomic DNA was extracted from herbarium specimens or silica-dried leaf samples using the DNeasy Plant mini kit (Qiagen, Hilden, Germany) following the manufacturer's instructions. We PCR amplified and sequenced one nuclear ribosomal (ITS1 = nuclear ribosomal internal transcribed spacer 1) and two plastid (trnL-F, rps 16 intron) DNA regions. For amplifying the ITS1, we used modified versions of the primers ITS5 and ITS2 (White et al. 1990); ITS5mod: 5'GGAAGTAAAAGTCGTAACAAGG'3 and ITS2mod: 5'GCTACGTTCTTCATCGATGC'3. We used the e and $\mathrm{f}$ primers of Taberlet et al. (1991) and the rpsF and rpsR2R primers of Oxelman et al. (1997) to PCR amplify the $\operatorname{trn} \mathrm{L}-\mathrm{F}$ spacer and the $r p s 16$ intron, respectively.

The genetic regions were amplified from $2 \mu \mathrm{L}$ unquantified genomic DNA in $25 \mu \mathrm{L}$ reactions using either the 
AmpliTaq DNA polymerase buffer II kit (Applied Biosystems, Foster City, CA, USA) containing $0.2 \mathrm{mM}$ of each dNTP, $0.04 \%$ bovine serum albumen (BSA), $0.01 \mathrm{mM}$ tetramethylammonium chloride (TMACl), and $0.4 \mu \mathrm{M}$ of each primer, or the Illustra ${ }^{\mathrm{TM}}$ puReTaq Ready-To-Go PCR Beads (GE Healthcare, UK) with $1.5 \mu \mathrm{L}(5 \mu \mathrm{M})$ of each primer and $20 \mu \mathrm{L}$ milliQ $\mathrm{H}_{2} \mathrm{O}$. We performed all amplifications on an Eppendorf Mastercycler EP gradient $\mathrm{S}$ under the following cycling conditions: $94^{\circ} \mathrm{C}$ for $2.5 \mathrm{~min}, 32$ cycles of $94^{\circ} \mathrm{C}$ for $30 \mathrm{~s}, 53^{\circ} \mathrm{C}$ for $30 \mathrm{~s}, 72^{\circ} \mathrm{C}$ for $50 \mathrm{~s}$, followed by $72^{\circ} \mathrm{C}$ for $4 \mathrm{~min}$. We purified the PCR products using $2 \mu \mathrm{L} 10$ times diluted ExoSAP-IT (USB Corporation, Cleveland, $\mathrm{OH}, \mathrm{USA}$ ) to $5 \mu \mathrm{L}$ PCR product, incubated at $37^{\circ} \mathrm{C}$ for $30 \mathrm{~min}$ followed by $15 \mathrm{~min}$ at $80^{\circ} \mathrm{C}$. Prepared amplicons for sequencing, contained $1 \mu \mathrm{L}$ purified PCR product, $1 \mu \mathrm{L}$ of $10 \mu \mathrm{M}$ primer (the same primer as used for the PCR), and 8 $\mu \mathrm{L}$ milliQ $\mathrm{H}_{2} \mathrm{O}$. After sequencing using the ABI BigDye Terminator sequencing buffer and the v3.1 Cycle Sequencing kit (Applied Biosystems), the sequences were processed on an ABI 3730 DNA analyser (Applied Biosystems). We assembled and edited the sequences using the ContiqExpress module in Vector NTI Advance ${ }^{\mathrm{TM}} 11.0$ (Invitrogen Corporation, CA, USA). A total of 137 new sequences were generated for the present study (Table 1).

TABLE 1. List with voucher information (taxon name, herbarium, voucher identification and country of origin) and GenBank accession numbers for DNA sequences used in the present study. Sequences generated for the present have accession numbers beginning with KU880. Abbreviations: $A .=$ Anthericum; $C .=$ Chlorophytum; Herb. $=$ voucher-holding herbarium; $\mathrm{n} / \mathrm{a}=$ not available.

\begin{tabular}{|c|c|c|c|c|c|c|}
\hline Taxon/Specimen No. & Herb. & Voucher ID & Locality & ITS1 & trnL-F & rps16 \\
\hline Anthericum angustifolium Hochst. (1) & ETH, O & Sebsebe 4670 & Ethiopia, Shewa, Changal area & KU880773 & KU880872 & KU880818 \\
\hline A. angustifolium (2) & ETH & Edwards et al. 5041 & $\begin{array}{l}\text { Ethiopia, N slopes of Alagi Mts } \\
\text { in Tigray }\end{array}$ & KU880774 & KU880873 & KU880819 \\
\hline A. corymbosum Baker (1) & $\mathrm{O}$ & Nordal 2276 & Ethiopia, Bale: $38 \mathrm{~km}$ E of Robe & KU880775 & KU880874 & KU880820 \\
\hline A. corymbosum (2) & ETH & Nordal 4601 & $\begin{array}{l}\text { Kenya, K4, Mua Hills, SW of } \\
\text { Nairobi }\end{array}$ & EU128949 & EU128939 & EU128959 \\
\hline A. jamesii Baker & ETH & $\begin{array}{l}\text { Melaku \& Kalaeb } \\
229\end{array}$ & $\begin{array}{l}\text { Ethiopia, c. } 10 \mathrm{~km} \text { f the turn to El } \\
\text { Siro wells }\end{array}$ & KU880776 & KU880875 & KU880821 \\
\hline $\begin{array}{l}\text { A. neghellense (Cufod.) Bjorå \& } \\
\text { Sebsebe }\end{array}$ & ETH, O & Nordal et al. 2218 & $\begin{array}{l}\text { Ethiopia, Sidamo: } 70 \mathrm{~km} \mathrm{~S} \text { of } \\
\text { Agere Maryam }\end{array}$ & KU880777 & KU880876 & KU880822 \\
\hline A. ramosum L. (1) & $\mathrm{O}$ & Bjorå 855 & $\begin{array}{l}\text { Switzerland, Berner Oberland, } \\
\text { Schrändli }\end{array}$ & KU880778 & KU880877 & KU880823 \\
\hline A. ramosum (2) & $\mathrm{O}$ & $1968-810-\mathrm{S}$ & Cult. Sweden, Stemåsa, Øland & KU880779 & KU880878 & KU880824 \\
\hline A. sp. & ETH & Sebsebe 6743 & Ethiopia, Bale: Mega & KU880780 & KU880879 & KU880825 \\
\hline Agave chrysantha Peebles. & $\mathrm{O}$ & $92-207 \mathrm{~S}$ & Cult. & KU880782 & KU880881 & KU880827 \\
\hline A. sp. & $\mathrm{O}$ & $96-195 \mathrm{~S}$ & Cult. & KU880781 & KU880880 & KU880826 \\
\hline $\begin{array}{l}\text { C. affine Baker var. curviscapum } \\
\text { (Poelln.) Hanid (1) }\end{array}$ & ETH & Nordal et al. 2289 & Ethiopia, Bale: Sof Omar & KU880783 & $\mathrm{n} / \mathrm{a}$ & KU880828 \\
\hline C. affine var. curviscapum (2) & ETH & Sebsebe et al. 4274 & Ethiopia, Bale: Sof Omar & KU880784 & $\mathrm{n} / \mathrm{a}$ & KU880829 \\
\hline C. affine var. affine (3) & $\mathrm{O}$ & Nordal \& Bjorå 4552 & Zambia N: Ntumbachusi falls & EF999985 & EU000019 & KU880830 \\
\hline C. africanum Engl. var. africanum & $\mathrm{O}$ & A. Bjørnstad 2054 & $\begin{array}{l}\text { Tanzania T7: Mbeya D., } \\
\text { Magangwe }\end{array}$ & EF999986 & EU000020 & $\mathrm{n} / \mathrm{a}$ \\
\hline $\begin{array}{l}\text { C. africanum var. silvaticum (Dammer) } \\
\text { Meerts }\end{array}$ & $\mathrm{O}$ & Nordal \& Bjorå 4621 & Kenya K3: Near Gilgil & EU000008 & EU000041 & EU128980 \\
\hline C. andongense Baker & $\mathrm{O}$ & Nordal \& Bjorå 5013 & $\begin{array}{l}\text { Tanzania T3: Pare D., near } \\
\text { Lembeni }\end{array}$ & EU128950 & EU128940 & EU128960 \\
\hline $\begin{array}{l}\text { C. blepharophyllum Schweinf. ex } \\
\text { Baker (1) }\end{array}$ & $\mathrm{O}$ & Hoell \& Nordal 24 & Zambia, B: Lukulu road & EF999989 & EU000023 & EU128961 \\
\hline C. blepharophyllum (2) & $\mathrm{O}$ & Hoell \& Nordal 94 & Zambia N, Lumangwe Falls & KU880785 & KU880882 & KU880832 \\
\hline C. blepharophyllum (3) & ETH & Tesfaye 1722 & $\begin{array}{l}\text { Ethiopia, Benishangul-Gumuz } \\
\text { Region }\end{array}$ & KU880786 & KU880883 & KU880833 \\
\hline C. cameronii (Baker) Kativu (1) & $\mathrm{K}, \mathrm{BR}$ & Reekmans 3955 & Burundi, Bubanza, Gihungwe & KU880787 & KU880884 & $\mathrm{n} / \mathrm{a}$ \\
\hline C. cameronii (2) & ETH & Sebsebe et al. 6093 & $\begin{array}{l}\text { Ethiopia, Benshangul-Gumuz, } \\
\text { Gojam }\end{array}$ & KU880788 & KU880885 & KU880834 \\
\hline C. colubrinum (1) & $\mathrm{O}$ & Nordal \& Bjorå 4535 & Zambia C: Kasanka & EF999991 & EU000025 & KU880835 \\
\hline C. colubrinum (2) & $\mathrm{O}$ & Mitchel 35 & Zambia: Sientambo, Kalome & EF999990 & EU000024 & KU880836 \\
\hline C. comosum (Thunb.) Jacques (1) & $\mathrm{O}$ & Bjorå 703 & $\begin{array}{l}\text { Tanzania T2: Kilimanjaro, Umwe } \\
\text { route }\end{array}$ & KU880789 & KU880886 & KU880837 \\
\hline C. comosum (2) & $\mathrm{O}$ & Bjorå 869 & Tanzania T2: Pare Mts & KU880790 & KU880887 & KU880838 \\
\hline C. comosum (3) & $\mathrm{O}$ & Bjorå 870 & Tanzania T2: Pare Mts & KU880791 & KU880888 & KU880839 \\
\hline C. comosum (4) & $\mathrm{O}$ & Hemp 3690 & $\begin{array}{l}\text { Tanzania T2: Kilimanjaro, forest } \\
\text { Old Moshi }\end{array}$ & EU128952 & EU128942 & EU128964 \\
\hline C. comosum (5) & $\mathrm{O}$ & Nordal 3162 & Zimbabwe, Cult. in Harare & EF999993 & EU000027 & KU880840 \\
\hline C. comosum (6) & $\mathrm{O}$ & Nordal 3803 & $\begin{array}{l}\text { South Africa: Cape, } \\
\text { Grootvatersbosch }\end{array}$ & EF999992 & EU000026 & EU128962 \\
\hline C. ducis-aprutii Chiov.(1) & ETH & $\begin{array}{l}\text { Elden, Tesfaye \& } \\
\text { Nordal } 1\end{array}$ & $\begin{array}{l}\text { Ethiopia, betw Robe and Sof } \\
\text { Omar }\end{array}$ & KU880792 & KU880889 & KU880841 \\
\hline C. ducis-aprutii (2) & ETH & Tesfaye 1783 & Ethiopia, Bale & KU880793 & KU880890 & KU880842 \\
\hline C. filipendulum Baker (1) & $\mathrm{O}$ & Nordal 3219 & $\begin{array}{l}\text { Zimbabwe E: Chipinge D., Kiledo } \\
\text { lodge }\end{array}$ & EU128956 & EU128944 & EU128969 \\
\hline C. filipendulum (2) & $\mathrm{O}$ & Poulsen 956 & $\begin{array}{l}\text { Uganda U2: Masindi D. Budongo } \\
\text { F.Res. }\end{array}$ & EF999994 & EU000028 & EU128968 \\
\hline
\end{tabular}

...continued on the next page 
TABLE 1. (Continued)

\begin{tabular}{|c|c|c|c|c|c|c|}
\hline Taxon/Specimen No. & Herb. & Voucher ID & Locality & ITS1 & $\operatorname{trn} \mathrm{L}-\mathrm{F}$ & $\operatorname{rps} 16$ \\
\hline C. gallabatense Schweinf. ex Baker (1) & $\mathrm{O}$ & $\begin{array}{l}\text { Elden, Tesfaye \& } \\
\text { Nordal } 7\end{array}$ & Ethiopia, Sof Omar & KU880794 & KU880891 & KU880843 \\
\hline C. gallabatense (2) & $\mathrm{O}$ & $\begin{array}{l}\text { Elden, Tesfaye \& } \\
\text { Nordal } 8\end{array}$ & Ethiopia, Sof Omar & KU880795 & KU880892 & KU880844 \\
\hline C. gallabatense (3) & ETH & Nordal 2225 & $\begin{array}{l}\text { Ethiopia, Shewa: } 39 \mathrm{~km} \mathrm{~S} \text { of } \\
\text { Agere Maryam }\end{array}$ & KU880796 & KU880893 & KU880845 \\
\hline C. gallabatense (4) & $\mathrm{O}$ & Nordal 4560 & Zambia N: E of Mununga & KU880797 & KU880894 & KU880846 \\
\hline C. cf. gallabatense (5) & $\mathrm{O}$ & Hoell \& Nordal 25 & Zambia B: Lukulu road & EF9999966 & EU000030 & EU128971 \\
\hline C. geophilum Peter ex Poelln. (1) & ETH & Herrmann 36 & $\begin{array}{l}\text { Ethiopia, Benshangul-Gumuz, } \\
\text { Gojam }\end{array}$ & KU880798 & $\mathrm{n} / \mathrm{a}$ & KU880847 \\
\hline C. geophilum (2) & $\mathrm{O}$ & Hoell \& Nordal 26 & ia B: Lukulu road & EF9999998 & EU000032 & EU128972 \\
\hline C. herrmannii (1) Nordal \& Sebsebe & ETH & Tesfaye et al. 1706 & $\begin{array}{l}\text { Ethiopia, Benshangul-Gumuz } \\
\text { Region }\end{array}$ & KU880799 & KU880895 & KU880848 \\
\hline C. herrmannii (2) & ETH & Tesfaye 1276 & $\begin{array}{l}\text { Ethiopia, Benishangul Gumuz } \\
\text { Region }\end{array}$ & KU880800 & KU880896 & KU880849 \\
\hline C. humifusum Cufod. & ETH, O & Nordal 2251 & jia, Sidamo, near Neghelle & KU880801 & & $\mathrm{n} / \mathrm{a}$ \\
\hline C. lancifolium Welw. ex Baker & $\mathrm{O}$ & 4576 & Kundabwika Falls & EU128957 & EU128945 & EU128973 \\
\hline C. longifolium Schweinf. & $\mathrm{O}$ & Nordal 1507 & $\begin{array}{l}\text { Zimbabwe S: Maswingo, near } \\
\text { Great Zimbabwe }\end{array}$ & EU000001 & EU000034 & KU880851 \\
\hline C. macrophyllum Asch. (1) & ETH & Herrmann 102 & ga, Tsheborona & KU880802 & KU880898 & KU880852 \\
\hline C. macrophyllum (2) & $\mathrm{O}$ & Nord & $51 \mathrm{~km} \mathrm{E}$ of Nel & 0002 & & 3974 \\
\hline C. macrosporum Baker & $\begin{array}{l}\mathrm{O} \\
\text { SRGH }\end{array}$ & Kativu 255 & Zimbabwe C: Chegutu & EU000004 & EU000037 & KU880853 \\
\hline C. mamillatum sp. nov. & ETH, O & $\begin{array}{l}\text { Elden, Tesfaye \& } \\
\text { Nordal } 9\end{array}$ & $\begin{array}{l}\text { Ethiopia, Welmel River, Fenkel } \\
\text { Kebale }\end{array}$ & KU880810 & KU880906 & KU880862 \\
\hline C. mamillatum sp. nov. & ETH & & & & & \\
\hline C. pendulum Nordal $\&$ & ETH & Nordal et al. 2260 & Ethiopia, Sidamo: Meg & KU880803 & & 80854 \\
\hline C. pendulum (2) & $\mathrm{O}$ & Nordal et al. 2294 & $\begin{array}{l}\text { Ethiopia: Bale Region, } 36 \mathrm{~km} \mathrm{~S} \\
\text { of Ginir }\end{array}$ & KU880804 & KU880900 & KU880855 \\
\hline C. polystachys Baker & $\mathrm{O}$ & Hoell \& Nordal 7 & $\begin{array}{l}\text { Zambia S: S of Zimba, } \\
\text { Monachongwe farm }\end{array}$ & EU000006 & EU000039 & KU880856 \\
\hline C. pseudocaule Tesfaye \& Nordal & ETH & Tesfaye 1731 & $\begin{array}{l}\text { Ethiopia, Wellega, } 15 \mathrm{~km} \mathrm{E} \mathrm{of} \\
\text { Asosa }\end{array}$ & KU880805 & KU880901 & KU880857 \\
\hline C. pteroce & $\mathrm{O}$ & 8 & & & & \\
\hline C. pubiflorum Baker & $\mathrm{O}$ & & Lununga Bridge & & & \\
\hline C. rubribracteatum (De Wild) Kativu & $\mathrm{O}$ & & & & & \\
\hline C. somaliense Baker & ETH & Hat & rea & KU88 & KU880905 & KU880861 \\
\hline C. sparsiflorum Baker (1) & WAG & Wieringa et al. 5921 & $\begin{array}{l}\text { Cameroon, Littoral Province, } \\
\text { Bekob camp }\end{array}$ & KU880812 & $\mathrm{n} / \mathrm{a}$ & KU880864 \\
\hline C. sparsiflorum (2) & WAG & Wieringa et al. 6452 & $\begin{array}{l}\text { Gabon, Haut-Ogooué, close to } \\
\text { Akiéni }\end{array}$ & KU880813 & $\mathrm{n} / \mathrm{a}$ & KU880865 \\
\hline C. sphachelatum (Baker) Kativu & $\mathrm{O}$ & Hoell \& Nordal 2 & $\begin{array}{l}\text { Zambia S: S of Zimba, } \\
\text { Monachongwe farm }\end{array}$ & EU000009 & EU000042 & KU880866 \\
\hline tiolatum (Baker) Kativu (1) & $\mathrm{O}$ & Nordal 15 & Zambia B: Road to Mouyo & EU000011 & EU0000 & KU880867 \\
\hline C. subpetiolatum (2) & ETH & & Ethiopia, Gojam: Assosa & KU880814 & KU880908 & \\
\hline C. suffruticosum Baker & $\mathrm{O}$ & A. Bjørnstad 2804 & $\begin{array}{l}\text { Kenya K7: Teita Dist, } 51 \mathrm{~km} \mathrm{NW} \\
\text { of Voi }\end{array}$ & EU000010 & EU000043 & KU880868 \\
\hline C. tetraphyllum Baker (1) & ETH & $\begin{array}{l}\text { Ensermu \& Lemessa } \\
3503\end{array}$ & $\begin{array}{l}\text { Ethiopia, Shewa: } 3 \mathrm{~km} \mathrm{~W} \text { of Addis } \\
\text { Abeba }\end{array}$ & KU880815 & KU880909 & KU880869 \\
\hline C. tetraphyllum (2) & ETH & Nordal 1030 & $\begin{array}{l}\text { Ethiopia, Shewa: betw. Gedo and } \\
\text { Fincha }\end{array}$ & KU880816 & KU880910 & KU880870 \\
\hline d. d.) Nordal & $\begin{array}{l}\mathrm{O} \\
\mathrm{ET}\end{array}$ & 5012 & & & & 128981 \\
\hline
\end{tabular}

\section{Alignment and phylogeny reconstructions}

Sequences from 69 accessions were manually aligned using BioEdit 7.0.9.0 (Hall 1999) and insertions/deletions (indels) were coded as present/absent and added to the matrices as additional, unordered characters using the program SeqState (Müller 2005) following the simple indel coding of Simmons \& Ochoterena (2000). The data were analysed using maximum parsimony and Bayesian inference phylogenetic methods. Maximum parsimony analyses were performed using NONA (Goloboff 1999) in combination with WinClada v. 1.0 (Nixon 1999-2002) applying the heuristic search option with 2000 replicates and maxtrees set to 10000 , and otherwise default settings. Parsimony jack-knifing was undertaken with 1000 replicates and otherwise default setting. To check for gene tree incongruence, we compared by eye the strict- and jack-knife consensus phylogenetic trees of the three genetic regions separately. For the Bayesian phylogenetic analyses, MrBayes 3.1.2 (Huelsenbeck \& Ronquist 2001; Ronquist \& Huelsenbeck 2003) was used with prior models of nucleotide substitution set according to the output of MrModeltest (Nylander 2004). Posterior probabilities were determined by running one cold and three heated chains for 4 million generations in parallel mode, saving trees every 1000th generation. The analyses were performed twice to check their convergence for the same topology. For the Markov Chain to have converged, the average standard deviation of split frequencies (ASDSF) should fall below 0.01 when comparing two independent runs. We discarded as burn-in $25 \%$ of the sampled trees, 
or the generations prior to the point where the ASDSF fell below 0.01 if passing the $25 \%$ limit. We summarized the remaining trees as a $50 \%$ majority rule consensus topology with Bayesian posterior probabilities (PP) of at least 0.9 and parsimony jack-knife (JK) support of at least $50 \%$. The preliminary parsimony consensus trees, from separate analyses of the three genetic regions, showed that only the plastid regions were congruent, although resolved to different extents and in different parts of the trees. Therefore, we established two datasets for the final analyses: (1) ITS1 with 69 accessions; and, (2) plastid DNA (pDNA) with 64 accessions. The Lifeportal server, University of Oslo, Norway (http://www.lifeportal.uio.no/root) was used for the model testing and Bayesian analyses.

\section{Morphometry and scanning electron microscopy}

We scored relevant morphological characters on 47 specimens of Chlorophytum sp. (= "shade form" of C. gallabatense), C. gallabatense, and C. comosum s.l., all deposited in ETH, K and/or O. Seed surfaces (testa ornamentation) of 17 specimens were investigated and photographed by use of a scanning electron microscope (SEM; Hitachi High Technologies and FE-PC-SEM software) after sputter coating with gold palladium.

\section{Results}

\section{Alignments and phylogenetic analyses}

The lengths in base pairs of the aligned genetic regions were: ITS1 317; rps 16855 ; and, trnL-F 268. The following numbers of indels were coded: ITS1 72; rps 1661 ; and, trnL-F 28. The estimated best fit models of nucleotide substitution were: GTR $+\mathrm{G}$ for ITS1 and $r p s 16$; and, HKY $+\mathrm{G}$ for $t r n \mathrm{~L}-\mathrm{F}$. Jackknife consensus trees with and without simple indel-coding were congruent. As the former had an overall higher resolution and branch support, all results presented herein are based on the indel-coded analyses.

TABLE 2. Morphological traits score for 47 specimens of Chlorophytum mamillatum (= "shade form" of C. gallabatense), C. gallabatense and C. comosum s.l. (see Table 1). The quantitative measures are given by range/mean.

\begin{tabular}{|c|c|c|c|c|c|c|c|c|c|c|}
\hline & $\mathrm{N}=$ & $\begin{array}{l}\text { No of } \\
\text { branches }\end{array}$ & $\begin{array}{l}\text { Peduncle } \\
\text { erect/lax }\end{array}$ & $\begin{array}{l}\text { Rhachis } \\
\text { scabrid }\end{array}$ & $\begin{array}{l}\text { Pedicel } \\
\text { length }(\mathrm{mm})\end{array}$ & $\begin{array}{l}\text { Ratio above/ } \\
\text { below joint }\end{array}$ & $\begin{array}{l}\text { Pedicel } \\
\text { papillose }\end{array}$ & $\begin{array}{l}\text { Flower } \\
\text { colour }\end{array}$ & $\begin{array}{l}\text { Capsule } \\
\text { papillose }\end{array}$ & $\begin{array}{l}\text { Root tubers on } \\
\text { lateral branches }\end{array}$ \\
\hline C. mamillatum & 4 & $4-7 / 5$ & lax & + & $5-7 / 5.7$ & $0.4-0.6 / 0.5$ & + & white & + & - \\
\hline C. gallabatense & 10 & $2-12 / 5.1$ & erect & + & $3-6 / 4.4$ & $0.2-0.4 / 0.3$ & + & green & slight & + \\
\hline $\begin{array}{l}\text { C. comosum } \\
\text { (S.Afr.) }\end{array}$ & 20 & $1-4 / 1.6$ & lax & $-(+)$ & $4-14 / 8.9$ & $0.2-0.5 / 0.4$ & $-(+)$ & white & - & - \\
\hline $\begin{array}{l}\text { C. comosum } \\
\text { (sensu FTEA) }\end{array}$ & 13 & $1-2 / 1.1$ & lax & $+(-)$ & $4-12 / 7.2$ & $0.2-0.5 / 0.4$ & $-(+)$ & white & - & - \\
\hline
\end{tabular}

Tree statistics from the maximum parsimony analyses of the two datasets were: (1) ITS1 - 32 most parsimonious trees (MPTs) of length 814 and with rescaled consistency index $(\mathrm{RC})=0.37$ and homoplasy index $(\mathrm{HI})=0.50$; and, (2) pDNA - 444 MPTs of length 2268 and with $\mathrm{RC}=0.6$ and $\mathrm{HI}=0.28$. In the Bayesian analysis of the ITS1 and pDNA datasets, the standard deviation of split frequencies (ASDSF) had fallen to 0.005877 and 0.009714 respectively, at termination, and the first 1000 generations ( $25 \%$ ) were discarded as burn-in.

The plastid regions separately rendered congruent topologies (not shown). Also the parsimony vs. the Bayesian analyses of all datasets were congruent, but resolved to different extents (not shown). The ITS1 vs. pDNA topologies were not congruent (Fig. 3a, b; clades discussed in the following are indicated with corresponding capital letters). One accession, C. zavattarii (Cufodontis 1939: 308) Nordal (1993: 65), included a high number of autapomorphic characters in the ITS1 alignment and attained incongruent positions in the ITS1 (clade E) vs. pDNA trees (clade F). Also two accessions of C. geophilum Peter ex Poellnitz (1943: 127) (Fig. 1G) attained incongruent positions (clade J vs. clade H). Apart from these incongruent patterns, the ITS1 and pDNA topologies supported by JK of at least $50 \%$ or PP of at least 0.9 were congruent, but resolved to different extents and in different parts of the trees (Fig. 3a, b). The genus Chlorophytum is monophyletic with low support in the plastid tree (Fig. 3b) and unresolved with respect to Anthericum in the ITS tree (Fig. 3a). Anthericum is paraphyletic in the plastid tree (Fig. 3b) and unresolved with respect to Chlorophytum in the ITS tree (Fig. 3a). Monophyly was supported for most species with multiple accessions included, except for a few, where rather a geographic pattern among accessions was evident (e.g. C. affine and C. comosum). The two accessions of $C$. affine var. curviscapum constitute a highly supported subclade (ITS; Posterior probabilities (PP) 1/Jackknife branch support (JK) 100, pDNA; PP 1/ JK 99) with C. humifusum Cufodontis (1939: 311) as its closest sister. Chlorophytum affine var. affine together with C. pubiflorum and C. polystachys forms a sister clade (PP 0.9) to the 


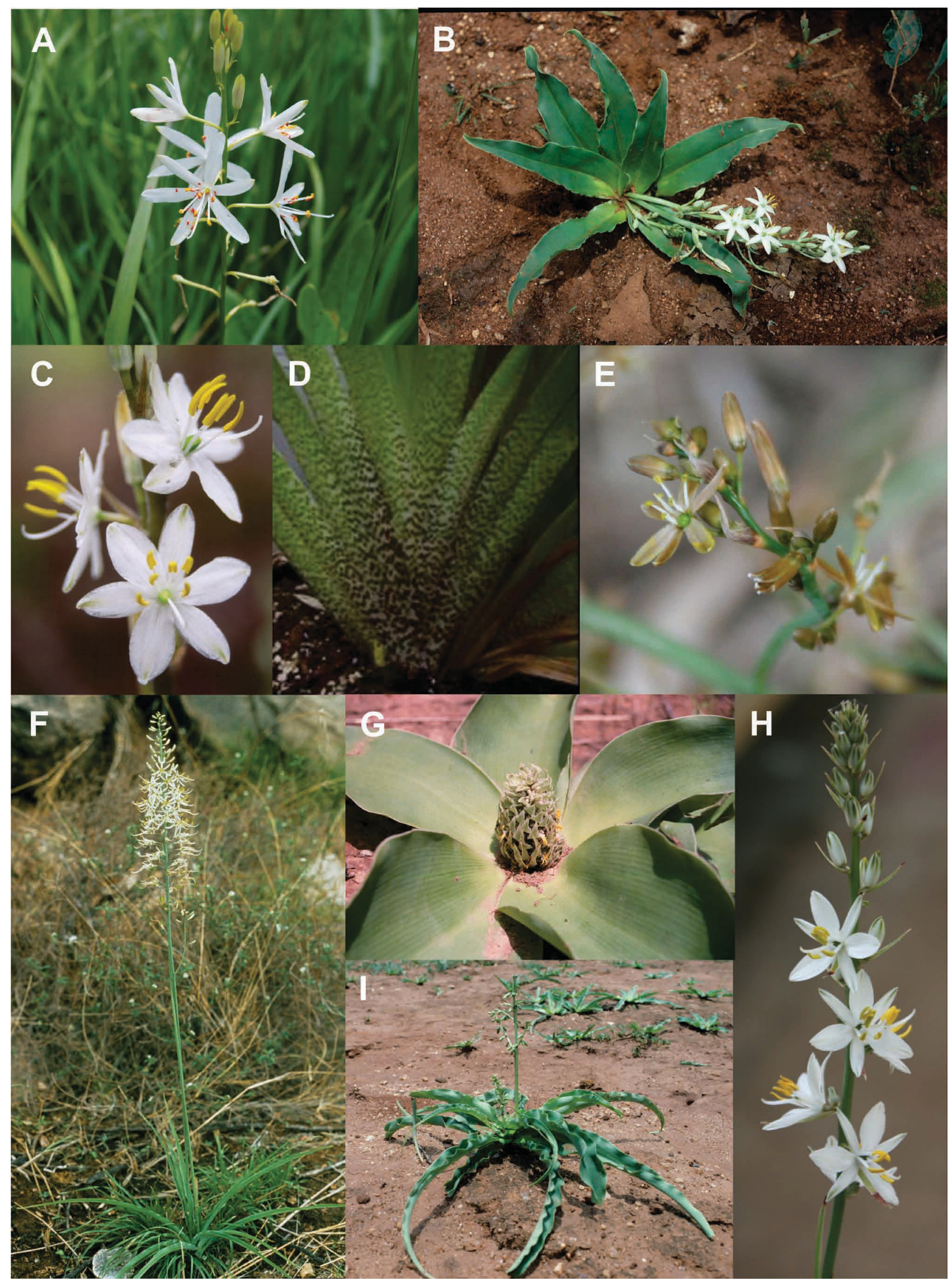

FIGURE 2. Photographs of studied Anthericum and Chlorophytum taxa. A. Anthericum ramosum, B. Anthericum neghellense, C. Chlorophytum subpetiolatum, D. Chlorophytum affine var. affine, E. Chlorophytum pseudocaule, F. Chlorophytum somaliense, G. Chlorophytum geophilum, H. Chlorophytum gallabatense, I. Chlorophytum ducis-aprutii. Photographs: Charlotte S. Bjorå (A), Inger Nordal (B, H, I), Gry S. Hoell (C, D, G), Tesfaye Awas (E), Mike Gilbert (F), Sebsebe Demissew (H). 
C. affine var. curviscapum clade. Chlorophytum comosum is not monophyletic. The two accessions from southern Africa constitute clade K, with support 1 (PP) and 94 (JK) in the ITS analysis and support 0.97 (PP) and 71 (JK) in the pDNA analysis. Within clade J, the Tanzanian accessions of $C$. comosum are found. In the pDNA tree, they form a clade (PP 0.97/JK 88), while in the ITS tree, three accessions form a clade (PP 0.99) and one accession is unresolved.

(a)

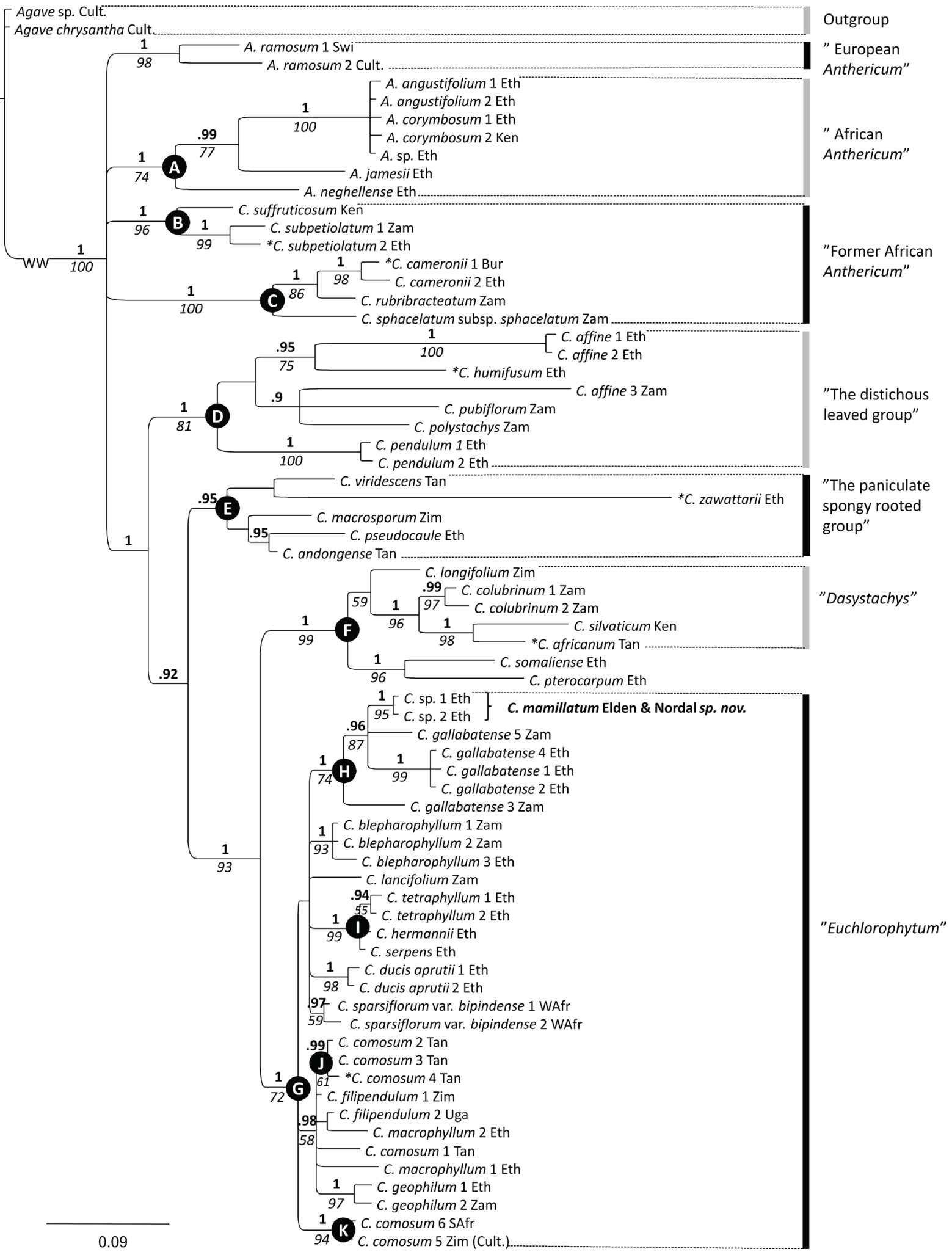


(b)

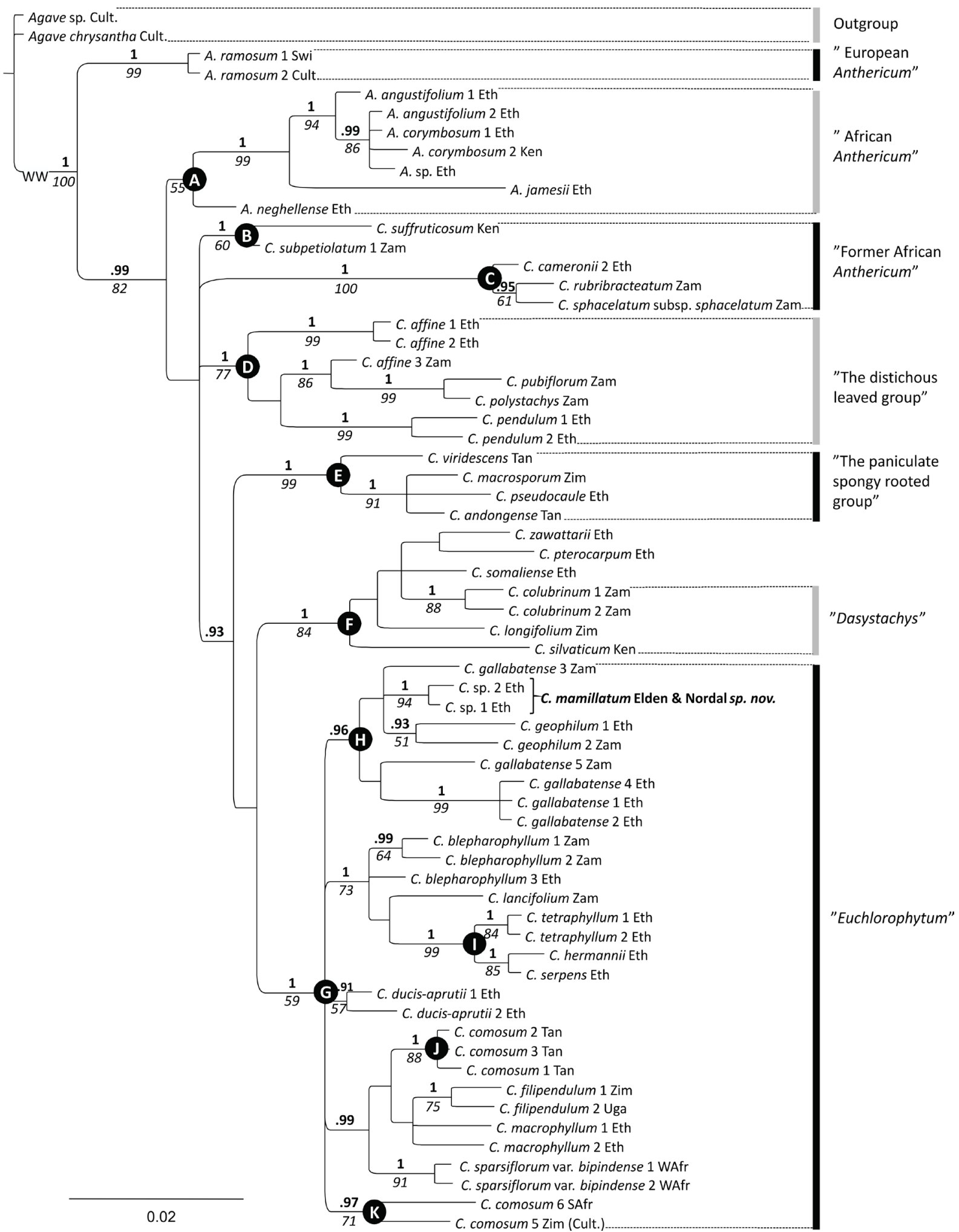

FIGURE. 3. The $50 \%$ majority rule consensus phylograms for members of Anthericum and Chlorophytum from Bayesian analyses of (a) the ITS1 matrix with 69 acessions and 389 characters (incl. 72 coded indels), and (b) the concatenated matrix of two plastid ( $r p s 16$ and $\operatorname{trn} \mathrm{L}-\mathrm{F}$ ) DNA regions, 64 accessions and 1230 characters (incl. 89 coded indels). The Bayesian posterior probability values (PP) of at least 0.9 are reported in bold above branches, whereas maximum parsimony jack-knife support (JK) of at least $50 \%$ are reported in italics below branches. Multiple accessions of the same species are numbered according to Table 1. "Morphological" groups (following Bjorå 2008) are indicated with bars to the right. Abbreviations: A. = Anthericum, Bur = Burundi, $C$. $=$ Chlorophytum, Cam $=$ Cameroon, Cult. $=$ Cultivated, Eth $=$ Ethiopia, Gab $=$ Gabon, Ken $=$ Kenya, SAfr $=$ South Africa, Swi $=$ Switzerland, Tan $=$ Tanzania, WAfr $=$ West Africa, Uga $=$ Uganda, Zam $=$ Zambia, Zim $=$ Zimbabwe. The clades discussed in the text are marked with capital letters. The zigzag branch in each tree represents a manual shortening of long branches to reduce the size of a broad figure. Accessions only present in the ITS1 tree are indicated with an asterisk. 

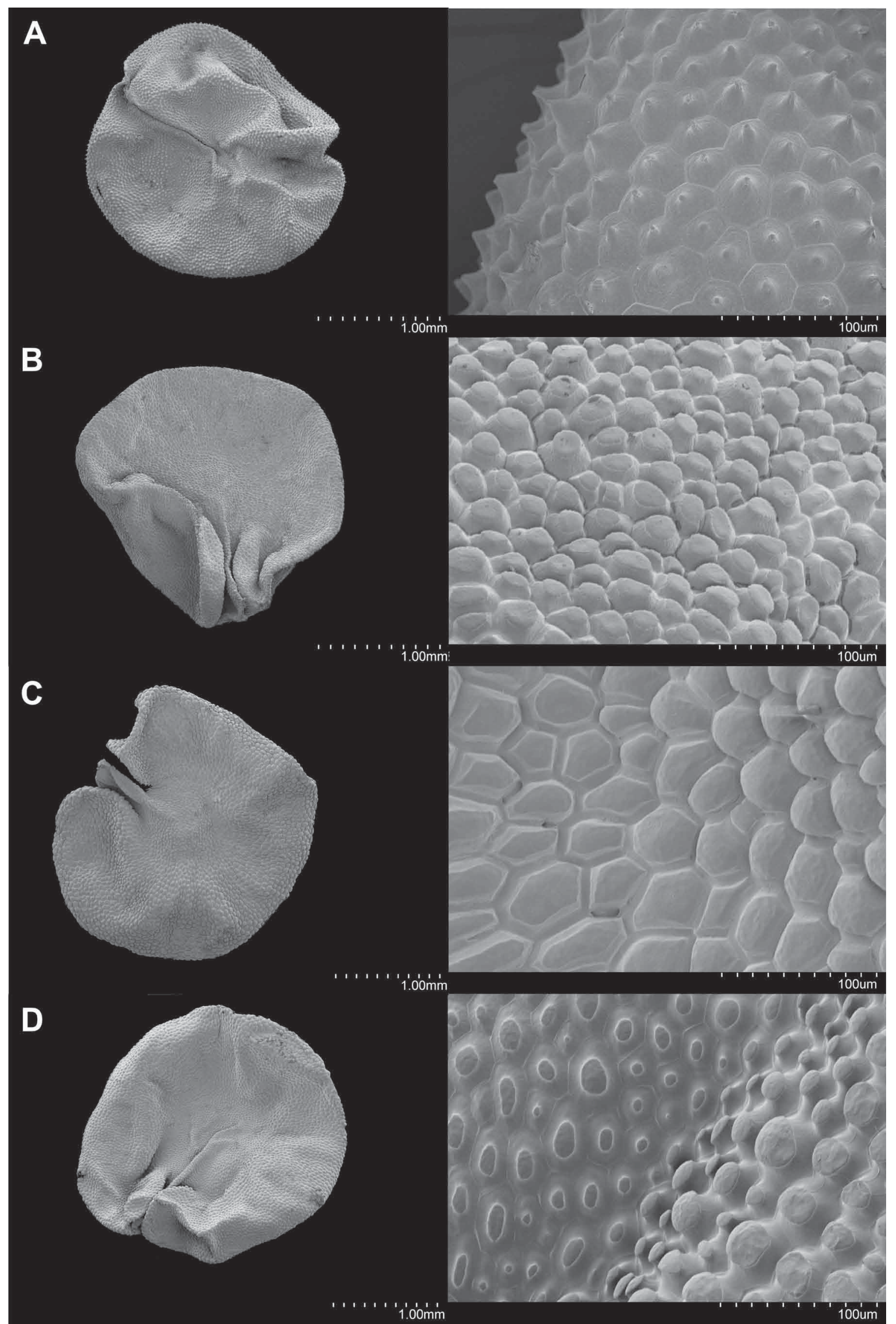

FIGURE. 4. Scanning electron micrographs of testa surface ornamentation in members of Chlorophytum. A. Chlorophytum mamillatum (= "shade form" of C. gallabatense), from Ethiopia, Elden et al. 9 (O), B. Chlorophytum comosum from Malawi, Brummitt \& Banda 9846 (K), C. Chlorophytum comosum sensu FTEA from Uganda, Lye 5536 (O). D. Chlorophytum gallabatense from Ethiopia, Nordal et al. $2225(\mathrm{O})$. 


\section{Morphometry and scanning electron microscopy}

The putative undescribed taxon, Chlorophytum sp. (= "shade form" of $C$. gallabatense), shares morphological traits both with $C$. gallabatense and C. comosum s.l. (Table 2). It differs from C. gallabatense by its lax, prostrate inflorescence (the latter having stout, erect peduncles and ballistic seed dispersal), by the pedicel joint being in a more or less middle position (not above the middle), the white (not green) flowers, and by having the root tubers along the main axes of the roots (not on lateral branches). Chlorophytum sp. differs from C. comosum by having branched inflorescences, slightly papillose capsules and lacking pseudovivipary.

Seeds of Chlorophytum sp., C. comosum and C. gallabatense are relatively flat (Fig. 4A-D), although with some irregular folding mainly around the area of the micropyle/hilum. The seeds of Chlorophytum sp. appear to display slightly more folding than the others. The outline in surface view of the testa cells are rounded to slightly angular for all studied specimens. The periclinal epidermal cell walls are somewhat raised and rounded for all but Chlorophytum sp., which has periclinal walls that are conical and outdrawn to a distinct papilla.

\section{Discussion}

\section{Phylogeny and speciation}

Reciprocal monophyly of the two genera Anthericum and Chlorophytum is not supported by our molecular data (Fig. 3a, b), corroborating previous findings with less data (Hoell 2005; Bjorå 2008; Elden 2010). Thus, even after the transfer of C. neghellense (Fig. 1B) to Anthericum, the generic delimitation is not satisfactory and will have to be studied further in a broader geographic and taxonomic context.

Clade A (Fig. 3a, b) comprises the African species of the genus Anthericum that are near-endemic to the Horn of Africa. Only A. corymbosum Baker (1877: 71) extends south to northernmost Tanzania. Anthericum angustifolium Hochstetter (1850: 332), A. corymbosum and Anthericum sp. constitute a clade with high support (ITS PP 1/JK 100; pDNA PP 1/JK 94). The two former are morphologically distinct: $A$. angustifolium has a completely reduced peduncle and rachis and long-pedicellate flowers in a pseudo-umbel and A. corymbosum has a well-developed peduncle and flowers in a racemose inflorescence. The former appears to be better adapted to heavy grazing by keeping flowers and fruits close to the ground. The two species show a vicariant distribution pattern in Ethiopia: A. angustifolium widely distributed in the central, northern and south-western Ethiopian highlands (Tigray, Gonder, Welo, Shewa and Gamo Gofa floristic regions; Fig. 2B) and in Eritrea; A. corymbosum distributed in the southern and eastern parts at somewhat lower elevations (Harerge, Bale and Sidamo floristic regions; Fig. 1B). Anthericum sp. from the Bale floristic region has only one flower per plant on a long pedicel, and might represent a depauperate $A$. angustifolium. However, more material is needed to conclude on this.

The strongly supported sister to the $A$. angustifolium/A. corymbosum clade (ITS PP $0.99 / \mathrm{JK} 77$; pDNA PP $1 / \mathrm{JK}$ 99 ) is $A$. jamesii Baker (1898: 490), distributed in the arid triangle between SE Ethiopia, NE Kenya and SW Somalia. Anthericum neghellense, a narrow endemic in southern Ethiopia, is in turn sister to all the other African Anthericum species. Given the distribution of the taxa in clade A, speciation within the African Anthericum has probably taken place in the Horn of Africa. Taxa in clades B and C (Fig. 3a, b) were earlier referred to the genus Anthericum sensu Obermeyer (1969), defined by capsules with horizontal ridges and irregularly folded seeds. These taxa were, however, transferred to the genus Chlorophytum by Kativu \& Nordal (1993). In our gene trees, these taxa do not constitute a monophyletic group, but as the two clades are part of a larger unsupported polytomy, monophyly cannot be ruled out. A sister relation between clades B and C does not gain much support from morphology, but both clades differs significantly from Clade A. Taxa of clade A have simple inflorescence nodes and no pedicel joint, whereas taxa of clade $\mathrm{C}$ have complex inflorescence nodes and pedicel joints (as the remaining clades $\mathrm{D}-\mathrm{G}$ ).

The E. African endemic C. suffruticosum Baker (1878: 326) (one of the very few woody species in the genus) and the widespread polymorphic C. subpetiolatum (Baker 1876: 302) Kativu (1993: 64) (Fig. 1C) are supported as sister species by both molecular datasets (Fig. 3a, b: clade B). Support for monophyly of different accessions of $C$. subpetiolatum across geographic distance (Ethiopia to Zambia; Fig. 3a) suggest this is a good species (ITS PP 1/JK 99).

The species of clade C, which receives strong support in both trees (Fig. 3a, b; PP 1/JK 100) are characterized by flowers with a zygomorphic androecium and pinkish coloration. In this clade, C. cameronii (Baker 1876: 314) Kativu (1993: 62) is the only Ethiopian representative, the clade otherwise comprising several species, distributed to the south and west of the Horn of Africa (Bjorå 2008). Chlorophytum cameronii is rare in Ethiopia, only found in lowlands close 
to the Sudanian border (Wellega and Illubabor floristic regions), suggesting it might have entered the Ethiopian flora from the south or west.

Several highly supported clades correspond well with the morphological groups introduced by Bjorå (2008) (Fig. 3a, b: clades D-G). The species comprising the strongly supported clade D (Fig. 3a, b) are characterised by a distichous leaf arrangement, a trait otherwise only found in clade C. Clade D divides into three subclades. Monophyly of $C$. affine is not supported by our molecular analyses; as the two varieties, var. affine and var. curviscapum, occur in different subclades. The two accessions of Ethiopian var. curviscapum represent a sister group to C. humifusum (ITS only; Fig. 3a), whereas C. affine var. affine (Fig. 1D) comes out in another subclade as sister to C. pubiflorum Baker (1876: 329) and C. polystachys Baker (1878: 326), all from Zambia. Chlorophytum affine var. affine is delimited from C. affine var. curviscapum by broader leaves (11-22 $\mathrm{mm}$ vs. up to $9 \mathrm{~mm}$ ) and by an erect, not basically curved peduncle. Material of C. affine from the Horn of Africa was earlier referred to C. tordense, which was sunk into C. affine var. curviscapum in FTEA by Nordal et al. (1997). Our results show that C. affine var. curviscapum is not conspecific with C. affine, and the name $C$. tordense should accordingly be re-instated (since when recognised at species level, $C$. tordense has priority to Anthericum curviscapum, the basionym of var. curviscapum). The third subclade consists of two Ethiopian accessions of the morphologically distinct C. pendulum Nordal \& Thulin (1993: 273).

Chlorophytum tordense and C. humifusum grow in disturbed, open and grazed areas and have developed prostrate inflorescences, a putative strategy to avoid grazing on flowers and fruits. Chlorophytum pendulum, on the other hand, with erect scapes and large hanging, pyramidal-shaped capsules, grows in more densely vegetated areas, without very heavy grazing. Chlorophytum humifusum and C. pendulum are near-endemics extending their distribution to southern Ethiopia and northern Kenya. The distribution of $C$. tordense outside Ethiopia is difficult to assess as its relation to $C$. affine var. curviscapum is not clear.

Clade E is strongly supported by all our molecular data (Fig. 3a, b), but only when C. zavattarii is excluded from the ITS analysis (not shown). This clade is also morphologically well-defined; all members have paniculate inflorescences and spongy roots without tubers. They are all relatively tall plants. Morphologically, C. zavattarii clearly belongs to clade E, and in the nuclear tree (Fig. 3a), it is sister to C. viridescens in the same clade. However, in the plastid tree (Fig. 3b), C. zavattarii is sister to C. pterocarpum Nordal \& Thulin (1993: 274) (in clade F), which does not belong to the paniculate spongy-rooted group. Chlorophytum zavattarii and C. pterocarpum occur in the same area and habitat, while C. viridescens Engler (1895: 140) grows further south in tropical East Africa. Thus, the molecular similarity of $C$. zavattarii to $C$. pterocarpum in the plastid tree might be a result of hybridization and chloroplast capture. The recently described C. pseudocaule (Fig. 1D, Tesfaye \& Nordal 2007) was, based on morphology, hypothesized to belong to "the paniculate spongy-rooted group". This is corroborated by our molecular data (Fig. 3a, b). This species is a narrow endemic from a seasonally wet meadow in the Wellega floristic region, close to the Sudanian border. The other species in clade E occur further south and particularly in the Zambesian vegetation region (sensu White 1983). The presence of two endemic species in clade E, namely $C$. zavattarii and $C$. pseudocaule, suggests that speciation may have taken place in the Horn of Africa.

Clade F is strongly supported by all molecular data (Fig. 3a, b), but only when C. zavattarii is excluded from the plastid tree (not shown). Morphologically, species within clade F share the traits of having one-flowered nodes (except C. longifolium Schweinfurth (1867: 294), which has multi-flowered nodes), triquetrous capsules, and completely flat seeds, densely stacked in the flat compartments of the fruit. Those species formerly referred to a separate genus, Dasystachys Baker (1898: 490) (see indication in Fig. 3a, b), form a poorly supported subclade within clade F in the nuclear tree (Fig. 3a) but receive no support from the plastid data (Fig. 3b). Dasystachys, which was sunk into Chlorophytum by Marais \& Reilly (1978), is characterized by having bell-shaped, closed flowers in a spicate inflorescence. Only two of the previous Dasystachys taxa, C. longifolium and C. africanum (Baker 1875: 160) Engler (1893a: 470) var. silvaticum (Dammer 1912: 365) Meerts (2012: 385) (treated as C. silvaticum in FEE and FTEA, see Meerts \& Bjorå 2012), occur in Ethiopia, although none of them are very common. Chlorophytum longifolium is found in northwest Ethiopia, close to the Sudanian border (Tigray and Gonder floristic regions), from where the species originally was described. It is otherwise widely distributed in the Sudano-Zambezian region (sensu White 1983) south to Botswana and Namibia. Chlorophytum africanum var. silvaticum is only recorded from the southernmost part of Ethiopia (the Sidamo floristic region), but is otherwise widely distributed south to Zimbabwe and Mozambique. Given their current distributions, we suspect that these two species have originated further south and reached Ethiopia from the west or south. Unfortunately, no Ethiopian material could be obtained for the present study

The "non-Dasystachys" members of clade F (C. somaliense Baker, in Baker \& Engler 1893: 469 and $C$. pterocarpum) do not display bell-shaped, closed flowers. Chlorophytum somaliense (Fig. 1F), widespread on the Horn of Africa (including Kenya), is a large plant, with a general appearance resembling the Dasystachys taxa. It has, 
however, conspicuous flowers with reflexed tepals and an exerted, zygomorphic androecium and clear herkogamy. We hypothesize that, in the course of evolution, this difference might have been pollinator driven. Chlorophytum pterocarpum, a narrow endemic in Ethiopia (the Sof Omar area in the Bale floristic region), is a small plant with small, inconspicuous, open flowers. It appears to be a dwarfed sister to C. somaliense, adapted to arid conditions. Chlorophytum pterocarpum is possibly autogamous as insect attractants appear to be lacking. It seems likely that species divergence among the "non-Dasystachys" members of clade F have taken place in Ethiopia.

Clade $\mathrm{G}$ is supported by all molecular data (ITS PP 1/JK 72; pDNA PP 1/JK 59) and corresponds to what has been referred to as "Euchlorophytum" (Bjorå 2008). This group is defined by having a basic chromosome number of $\mathrm{x}=7$, contrasting the other Chlorophytum species with $\mathrm{x}=8$. Representatives of the genus Chlorophytum outside the Euchlorophytum clade are, with few exceptions, found in savanna grassland, bushland and woodland. The members of the Euchlorophytum clade seem to have adapted to more shady forest environments, including riverine forests.

Clade H, which might be denoted the C. gallabatense complex, is supported by the ITS data (Fig. 3a, PP 1/JK 74) but receives less support by pDNA (Fig. 3b, PP 0.96). In the pDNA tree (Fig. 3b), clade H also includes C. geophilum (in clade J of the ITS tree; Fig. 3a). Also without $C$. geophilum, the $C$. gallabatense clade, distributed from Ethiopia west to Senegal and south to Zimbabwe, is rather heterogeneous molecularly, and two subclades are evident: (1) two Ethiopian accessions of Chlorophytum sp., and (2) three Ethiopian accessions of C. gallabatense. The two Zambian accessions of C. gallabatense do not group with the Ethiopian accessions (Fig. 3a, b). Representatives of the C. gallabatense clade created, as mentioned, problems when writing up the FEE (Nordal 1997). It was questioned in the flora whether specimens, here referred to Chlorophytum sp., represents shade forms of $C$. gallabatense, or whether they represented forms of the southern African C. comosum complex. Our molecular data suggest that Chlorophytum sp. belongs in the C. gallabatense complex. Yet, the two accessions of Chlorophytum sp. group with high molecular support (ITS PP 1/JK 95; pDNA PP 1/JK 94), suggesting it represents a distinct evolutionary lineage that also gains support from the morphological investigations; Chlorophytum sp. is distinct from C. gallabatense in several independent morphological traits (Table 2). The morphology of the inflorescence indicates that mechanism of seed dispersal differs between the two: Chlorophytum sp. releases the seeds on the ground at some distance from the mother plant due to the fairly long and lax inflorescence, whereas $C$. gallabatense, with its stiff erect peduncle, displays all traits of a typical ballist. In addition, the two species differ in the morphology of the seed testa. Chlorophytum sp. should be recognised at the level of species and is described below as $C$. mamillatum Elden \& Nordal (due to the small nipple-like projections of the testa cells; Fig 4A). This action renders the species C. gallabatense paraphyletic in the molecular trees (Fig. $3 \mathrm{a}$, b: clade H). Moreover, the molecular results indicate that the species $C$. gallabatense is heterogeneous and that Zambian specimens represent one or more distinct evolutionary lineages that may deserve the rank of species. The $C$. gallabatense complex should be investigated further with a broader geographic sampling.

As mentioned above, the plastid versus nuclear trees are ambiguous when it comes to the phylogenetic placement of C. geophilum (Fig. 3a, b: clades $\mathrm{J}$ and $\mathrm{H}$, respectively). Chlorophytum geophilum is only found within the Illubabor and Gonder floristic regions in the extreme west of Ethiopia, but is otherwise widely distributed in savanna areas in Africa, west to Burkina Faso, and south to Malawi and Zambia. The grouping of Zambian and Ethiopian accessions indicates monophyly of the species, but further investigations are needed to confirm this and also its relations within the "Euchlorophytum" clade.

Monophyly is supported also for the heterogeneous C. blepharophyllum complex (cf. Bjorå 2008), but only in the ITS tree (Fig. 3a, PP 1/JK 93). In Ethiopia, C. blepharophyllum (Fig. 2B) is found in the western parts of Tigray, Gojam, Wellega and Illubabor floristic regions. Otherwise, C. blepharophyllum is widespread in tropical Africa, from Ethiopia west to Senegal, through Central and East Africa, south to Angola, Zimbabwe, and Mozambique. Taxon delimitation in the $C$. blepharophyllum complex should be investigated further with a broader taxonomic and geographic sampling.

Clade I, a well-supported subclade of clade G (PP 1/JK 99), comprises three Ethiopian species, the near-endemic C. tetraphyllum Baker (1876: 328) and the narrow endemics, C. herrmannii and C. serpens (Fig. 3a, b). This clade is characterized by plants with more or less prostrate leaves and inflorescences, which might have evolved as a strategy to avoid grazing. Chlorophytum tetraphyllum was originally described from Yemen by the younger Linnaeus, but has its main distribution in the Ethiopian highlands. Sebsebe \& Nordal (2010) proposed that $C$. tetraphyllum should be transferred to Anthericum. The morphological basis for the proposed transfer was that $C$. tetraphyllum apparently lacks pedicel articulation (Nordal 1997). However, the peduncle and rachis are otherwise so reduced that the diagnostic character of complex nodes or not is difficult to evaluate. The new combination, Anthericum tetraphyllum (Linnaeus fil. 1782: 200) Nordal \& Sebsebe (2010: 133), was proposed. The name was, however, not validly published, as an exact reference to the basionym Scilla tetraphylla Linnaeus fil. (1782: 200) was not included. Our results clearly show that the taxon belongs in Chlorophytum. 
Chlorophytum herrmannii and C. serpens are only known from a few populations in the far west of Ethiopia close to the Sudanian border (Wellega and Gojam floristic region). In this clade, speciation appears to have taken place locally in W Ethiopia.

The two accessions of the Ethiopian endemic C. ducis-aprutii Chiovenda (1929: 370) (Fig. 1I) constitute a well-supported subclade within clade G (Fig. 3a, b; ITS PP 1/JK 98; pDNA PP 0.91/JK 57). Agegnehu et al. (2012) documented that the chromosome number of this species is $2 n=30$, and as such represents $x=15$ within the otherwise homogenously $\mathrm{x}=7$ "Euchlorophytum" clade. The most probable interpretation is that the species is an allopolyploid between an $\mathrm{x}=7$ and an $\mathrm{x}=8$ taxon. Based on morphology, we suspect that $C$. macrophyllum Ascherson (1867: 294), widespread in Ethiopia, might be the putative $\mathrm{x}=7$ parent. When it comes to the putative $\mathrm{x}=8$ parent, the size of the plant (60-200 cm high), the spongy roots without tubers, the bracteate peduncle and the branched inflorescence might indicate a member of "the paniculate spongy rooted group" (cf. Fig. 3a, b: clade E). Nordal et al. (1990) published the chromosome number $2 \mathrm{n}=32$ for $C$. ducis-aprutii. However, the preparation was not optimal and the result could, in hindsight, be interpreted both as $\mathrm{n}=15$ or $\mathrm{n}=16$. The hypothesized allopolyploid origin of $C$. ducis-aprutii might be further illuminated by various molecular approaches. In FEE, a somewhat deviating form of $C$. ducis-aprutii was recorded from Eritrea. The taxonomic belonging of this form needs further investigation.

Our molecular results clearly show that C. comosum, as circumscribed in FTEA (Nordal et al.1997), is highly heterogeneous (Fig. 3a, b; subclade J and K). The species was described from South Africa by Thunberg already in 1794 , and the name is accordingly attached to the plants of clade K. This means that the East African C. comosum in clade J, and probably also the Ethiopian plants (unfortunately, material not available for molecular analyses), should be referred to a different species. Genetic diversity in relation to geographic distance should be further analysed in $C$. comosum.

The two species C. macrophyllum and C. filipendulum Baker (1878b: 260) have often been confused in herbaria and literature (e.g., Nordal et al. 1997). Chlorophytum macrophyllum is described from the Tigray floristic region in Ethiopia and is otherwise widely distributed in tropical Africa from Ethiopia west to Sierra Leone and south to Mozambique, growing in dense woodland and transitional vegetation woodland/forest within Sudano-Zambezian vegetation (White 1983). Chlorophytum filipendulum is a typical Guineo-Congolean (sensu White 1983) rain forest species; in Ethiopia only found in the south-west (Kefa floristic region). Morphologically the two species differ in flower traits. Chlorophytum macrophyllum has large showy flowers (tepals 9-15 $\mathrm{mm}$ long) and anthers longer than the filaments. Chlorophytum filipendulum has inconspicuous flowers (tepals 5-7 mm long) and anthers shorter than the filaments. Due to low resolution, our molecular results do not clarify the relation. The delimitation within this complex needs further attention.

\section{Biogeographical aspects}

The near-endemic species of Anthericum and Chlorophytum in Ethiopia fall mainly within two areas (Fig. 2B). The first of these evolutionary hotspots is found in the lowland south and east of Bale Mountains, i.e. the Sidamo and Bale floristic regions, (some also extending into adjacent parts of Kenya and Somalia) and includes the following six species: A. neghellense, C. bifolium, C. humifusum, C. pendulum, C. pterocarpum, and C. zavattarii. This putative centre of endemism was already recognized by Nordal et al. (2001). The following three species occur within the same area, but extend further east to the Harerge floristic region: A. jamesii, C. ducis-aprutii and Chlorophytum sp. (i.e. C. mamillatum; described below). Speciation in this southern to eastern group of endemics has taken place in several clades, indicating that the relative high number of endemics in the area is not due to radiation in one particular clade, but is spread across the two genera. The areas, where the above mentioned endemic species are distributed, are characterised ecologically by bimodal rainfall with the first peak between September and November and the second between March and May. The vegetation is dominated by Acacia-Commiphora woodland and bushland. The AcaciaCommiphora woodland is divided into two subtypes. The areas where the endemic Anthericum and Chlorophytum species occur belong to the subtype Acacia-Commiphora woodland and bushland proper ("ACB" of Friis et al. 2010), characterized by drought-resistant trees and shrubs.

The second evolutionary hotspot is found in the lowland of Gojam and Wellega, close to the Sudanian border, and includes the following endemic species: $C$. herrmannii, $C$. pseudocaule and $C$. serpens. This centre of endemism was also recognized by Sebsebe et al. (2005). Speciation seems to have taken place in both clades E and I (Fig. 3a, b). The region is characterised by unimodal rainfall between May and September. The vegetation is dominated by Combretum-Terminalia woodland and wooded grassland (Friis et al. 2010). This vegetation type is characterized by small to moderate- sized trees with fairly large deciduous leaves and a well developed tall grass stratum. The grass stratum burns during the dry season and the vegetation in general is adapted to fire. 
The two remaining near-endemics, A. angustifolium (clade A) and C. tetraphyllum (clade I), have a fairly wide distribution in the Ethiopian highland and often grow in heavily grazed, even over-grazed, areas. The area with the highest density of endemics is, as mentioned, the lowland surrounding the Bale Mountains. During the Quaternary climatic fluctuations, plants might have found rather stable niches by moving up and down the mountain according to changes in particular rainfall.

When it comes to the western center of endemicity, Sebsebe et al. (2005) suggested that the complex topography and the relatively reliable orographic rain on the western Ethiopian escarpment, together with the hinterland of deep river valleys, provided small refugia during the periods of adverse climatic conditions. This may have secured niches where species could survive unfavourable periods. The best conditions for such niches are likely to have been in the most topographically and geologically complex areas in the lower reaches and at the mouth of the biggest river system in western Ethiopia, the gorges of the Blue Nile River and its tributaries.

\section{Taxonomic conclusion}

In addition to understand the phylogenetic sister group relations of the Ethiopian endemic species of Chlorophytum, as discussed above, an aim of the paper was to sort out the variation pattern in the C. gallabatense complex, and particularly to establish the taxonomic status of the so-called "shade form". Based on both molecular and morphological evidence, this form, herein mostly referred to as Chlorophytum sp., deserves taxonomic recognition at the level of species and is formally described below.

\section{Chlorophytum mamillatum Elden \& Nordal, sp. nov. (Fig. 5)}

Species nova C. gallabatensi affinis, sed eo differt tuberibus secus axem radicis non in ramis lateralibus dispositis; inflorescentiis laxis prostratis; floribus albis non viridibus; testis periclinalibus cellularum mamillatis.

A species related to $C$. gallabatense, differing by having root tubers along the root axis, rather than on lateral branches; lax, prostrate inflorescences, not stiffly erect; white flowers, not greenish; and nipple-like projections on the periclinal seed cell walls.

Type:-ETHIOPIA. Bale floristic region: $10 \mathrm{~km} \mathrm{~N}$ of Dolo Menna (Masslo) on the road to Goba, 6 252' N 3944'E, $1500 \mathrm{~m}$ of elevation, 25 October 1984, I. Friis, M.G. Gilbert \& K. Vollesen 3459 (holotype ETH!; isotype K!).

Perennial with short rhizome, roots ca. $2 \mathrm{~mm}$ in diameter, with distal tubers, $20-40 \times 5-10 \mathrm{~mm}$. Leaves rosulate, strapshaped, 150-600 × 15-30 mm, glabrous with narrow hyaline margin. Inflorescence paniculiform, length (including peduncle) 250-500 $\mathrm{mm}$ with 2-7 branches. Bract supporting branches up to $12 \mathrm{~mm}$ long, usually shorter; bracts supporting flower nodes up to $3 \mathrm{~mm}$ long, with dark brown margin. Number of flowers per node 1-3(4). Pedicel length 3-5(-7) $\mathrm{mm}$, with a joint disposed from the middle to upper part, slightly papillose below the joint (at least in fresh material). Flowers star-shaped, white with greenish apex; tepals free, lanceolate, 4-5 × 1.5-2 mm; filaments filiform, 2-3 mm long, slightly papillose, white; anthers $1-2 \mathrm{~mm}$ long, yellow; style 4-5 $\mathrm{mm}$ long, bent with a minute stigma. Capsule triangular in cross section, papillose, ca. $4 \times 6 \mathrm{~mm}$; seeds 3 or 4 per locule, diameter $2 \mathrm{~mm}$, flat and irregularly folded, periclinal walls of epidermal cells conical and outdrawn to a distinct papilla (Fig. 4).

Distribution: - The Bale and Harerge floristic regions, Ethiopia (Fig. 2B).

Additional specimen examined: -ETHIOPIA. Bale floristic region: $10 \mathrm{~km} \mathrm{~N}$ of Dolo Menna (Masslo) on the road to Goba, $06^{\circ} 25^{\prime}$ N, $39^{\circ} 44^{\prime}$ E, 1500 m elevation, 25 October 1984, I. Friis, M. G. Gilbert \& K. Vollesen 3459 (ETH, K); Harenna Forest, 14 km on Dello Mena-Goba road, 06²7’ N, 3944' E, 1560 m elevation, 11 June 1986, M. Tadesse 4671 (ETH); Dello Awraja in Harenna forest, ca. $2.2 \mathrm{~km}$ from turn-off from Shisha River, ca. $20 \mathrm{~km}$ on Dello Mena-Goba road, 06²9’ N, 39452’ E, 1530 m elevation, 13 August 1986, M. Tadesse 5291 (ETH); Harenna Forest near Yadot River, 1625 m elevation, 2 May 1990, L. Nogatu and M. Tadesse 9076 (ETH); Welmel River, Fenkel Kebale, $06^{\circ} 26.576^{\prime}$ N, 39³9.153' E, ca. 1500 m elevation, 15 December 2007, M. Elden, I. Nordal, T. Awas \& S.

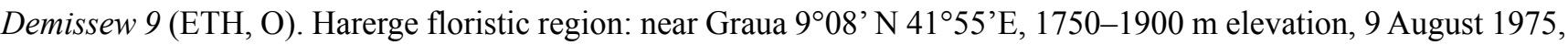
M.G. Gilbert 4019 (K); Harar-Jijiga road, 13 km, 1550 m elevation, 17 August 1975, M.G. Gilbert \& M. Thulin 41 (K); Uadendeo Plateau, $36 \mathrm{~km}$ ESE of Harar on the road to Jijiga, 9 ${ }^{\circ} 04^{\prime}$ N, $42^{\circ} 23^{\prime}$ E, $1520 \mathrm{~m}$ elevation, 17 August 1972, W. Burger 2074 (K); East of Gara Gora, 900' N, 42 ${ }^{\circ} 18^{\prime}$ E, 1220-1340 m elevation, 28 July 1963, W. Burger $3050(\mathrm{~K})$. 


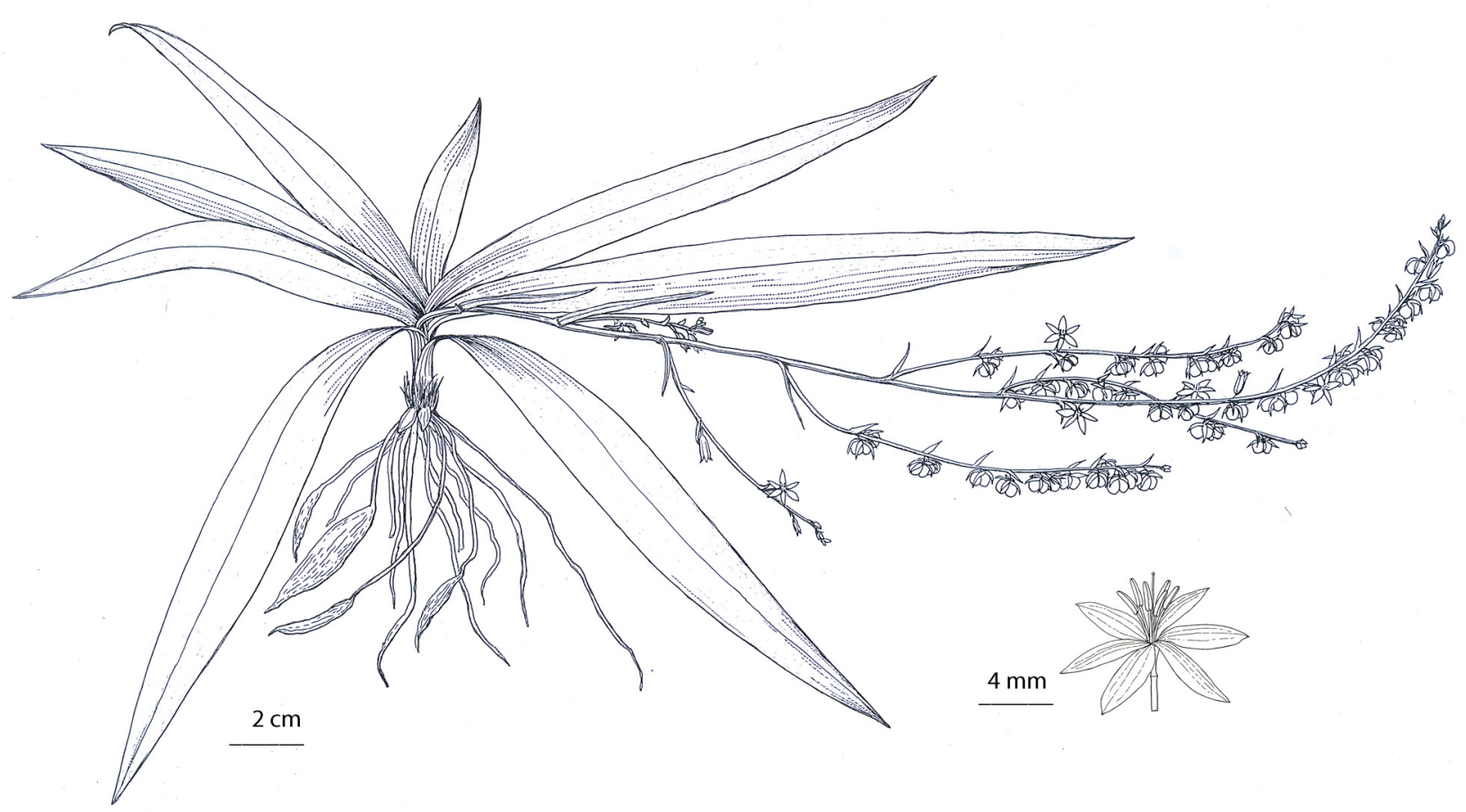

FIGURE 5. Chlorophytum mamillatum based on Gilbert \& Tulin 41 (K). A. Habit. B. Detail of flower. Artist: Svetlana Voronkova.

\section{Acknowledgements}

We thank the curators in BRLU, ETH, K and WAG for the loan of material, in particular Prof. P. Meerts and Dr. J. Wieringa for providing samples collected in silica gel. We also thank Lisbeth Birgitte Thorbek and Cecilie Mathiesen for assistance with molecular analyses, Melinka Butenko for assistance with scanning electron microscopy and Svetlana Voronkova for the line drawing. We thank the editor and two anonymous reviewers who improved the quality of this paper.

\section{References}

Agegnehu Waasse, Kifle, D. \& Sebsebe, D. (2012) Some Ethiopian species of Chlorophytum and Anthericum, karyotype analysis. Lap Flambert Academic Publishing, Saarbrücken, pp. 1-79.

Angiosperm Phylogeny Group [APG III] (2009) An update of the Angiosperm Phylogeny Group classification for the orders and families of the flowering plants: APG III. Botanical Journal of the Linnean Society 161: 105-121.

http://dx.doi.org/10.1111/j.1095-8339.2009.00996.x

Ascherson, P.F.A. (1867) Chlorophytum macrophyllum. In: Schweinfurth, G. (Ed.) Beitrag zür Flora Etiopiens. G. Reimer. Berlin, 307 pp.

Baker, J.G. (1875) The botany of the Speke and Grant expedition. Monocotylidones petaloideae. Transactions of the Linnean Society of London 29: 151-163.

http://dx.doi.org/10.1111/j.1096-3642.1875.tb00234.x

Baker, J.G. (1876) Revision of the genera and species Anthericeae and Eriospermeae. Journal of the Linnean Society, Botany 15: 253363.

http://dx.doi.org/10.1111/j.1095-8339.1876.tb00247.x

Baker, J.G. (1877) Descriptive notes on a few of Hildebrandt's East African Plants. Journal of Botany, British and Foreign 15: 65-77.

Baker, J.G. (1878a) Decriptions of new and little known Liliaceae. Journal of Botany, British and Foreign 16: 321-326.

Baker, J.G. (1878b) Report on the Liliaceae, Iridaceae, Hypoxidaceae, and Haemodoraceae of Welwitch`s Angolean Herbarium. 
Transactions of the Linnean Society of London, Botany 1: 245-273.

http://dx.doi.org/10.1111/j.1095-8339.1878.tb00040.x

Baker, J.G. \& Engler, A. (1893) Liliaceae africanae In: Engler, A. Botanische Jahrbücher für Systematik, Pflanzengeschichte und Pflanzengeographie 15: 467-479.

Baker, J.G. (1898) Anthericum. Flora of Tropical Africa 7(3): 477-493.

Bjorå, C.S. (2008) Phylogeny, speciation and biogeography - a study of Crinum and Chlorophytum. PhD thesis, Faculty of Mathematics and Natural Sciences, University of Oslo, 229 pp.

Chiovenda, E. (1916) Resultati scientifici della missione Stefanini-Paoli nella Somalia Italiana. Appendice: Le raccolte di Mangano, Scassellati, Mazzocchi e Provenzale in Somalia. 241, Firenze: Tipografia Galletti e Cocci.

Chiovenda, E. (1929) Le collezioni botaniche di S.A.R. il Duca degli Abruzzi alla sorgente dell Uebi Scebeli. Nuovo Giornale Botanico Italiano; e Bollettino della Societa Botanica Italiano, Firenze, 371 pp.

Cufodontis, G. (1939). Liliaceae. Missione Biologica nel paese dei Borana. 4: 306-324.

Dammer, C.L.U. (1905) Beiträge zur Flora von Afrika. Botanische Jahrbücher für Systematik, Pflanzengeschichte und Pflanzengeographie 38: $62-66$.

Dammer, C.L.U. (1912) Liliaceae africanae. Botanische Jahrbücher für Systematik, Pflanzengeschichte und Pflanzengeographie 48: $360-366$.

Elden, M. (2010) Studies in the genera Anthericum and Chlorophytum with emphasis on Ethiopian taxa. Master's thesis, Faculty of Mathematics and Natural Sciences, University of Oslo, 60 pp.

Engler, H.G.A. (1893a) Chlorophytum africanum. in Baker \& Engler. Liliaceae africanae. Botanische Jahrbücher für Systematik, Pflanzengeschichte und Pflanzengeographie 15: 467-479.

Engler, H.G.A. (1893b) Chlorophytum somaliense. in Baker \& Engler. Liliaceae africanae. Botanische Jahrbücher für Systematik, Pflanzengeschichte und Pflanzengeographie 15: 467-479.

Engler, H.G.A. (1895) Fam. Liliaceae, Die Pflanzenwelt Ost-Afrikas und der Nachbargebiete. Teil C. Verlag G. Reimer, Berlin, 141 pp.

Friis, I., Sebsebe Demissew \& van Breugel, P. (2010). A new potential vegetation map of Ethiopia. Biologiske Skrifter 58: 1-307.

Goloboff, P. (1999) NONA (ver. 1.9). Software published by the author, San Miguel de Tucumán, Argentina. Available from: http://www. cladistics.com (accessed 1 February 2017)

Hall, T.A. (1999) BioEdit: a user-friendly biological sequence alignment editor and analysis program for Windows 95/98/NT. Nucleic Acids Symposium Series 41: 95-98.

Hanid, M.A. (1974) The identity of Chlorophytum affine (Liliaceae) and its range of variation in Africa. Kew Bulletin 29: 585-591. http://dx.doi.org/10.2307/4108001

Hochstetter, C.F.F. (1850) Anthericum angustifolium. In: Richard, A. (Ed.) Tentamen florae abyssinicae. Vol 2. A. Bertrand, Paris. 518 pp.

Hoell, G. (2005) The genera Anthericum and Chlorophytum (Anthericaceae), evolution and delimitation. Cand. Scient. thesis, Faculty of Mathematics and Natural Sciences, University of Oslo, 73 pp.

Huelsenbeck, J.P. \& Ronquist, F. (2001) MRBAYES: Bayesian inference of phylogenetic trees. Bioinformatics 17: 754-755. http://dx.doi.org/10.1093/bioinformatics/17.8.754

Jacques, H.A. (1862) Notes sur des plantes nouvelles, rares ou peu connues. Journal de la Société Imperiale et Centrale d'Horticulture 8: $343-345$

Kativu, S. (1993) New combinations of African species in the genus Chlorophytum (Anthericaceae). Nordic Journal of Botany 13: 5965. http://dx.doi.org/10.1111/j.1756-1051.1993.tb00016.x

Kativu, S. \& Nordal, I. (1993) New combinations of African species in the genus Chlorophytum (Anthericaceae). Nordic Journal of Botany 13: 59-65.

http://dx.doi.org/10.1111/j.1756-1051.1993.tb00016.x

Kativu, S., Hoell, G., Bjorå, C.S. \& Nordal, I. (2008) Anthericaceae. In: Timberlake, J.R. \& Martins, E.S. (Eds.) Flora Zambesiaca 13: 34-89.

Ker Gawler, J.B. (1807) Chlorophytum inornatum. Curtis’s Botanical Magazine 27: t. 1071. http://dx.doi.org/10.5962/bhl.title.669

Linnaeus, C. (1753) Species Plantarum, vol 1. Laurentius Salvius, Stockholm, 560 pp.

Linnaeus fil., C. (1782) Supplementum Plantarum Systematis Vegetabilium Editionis Decimae Tertiae, Generum Plantarum Editiones Sextae, et Specierum Plantarum Editionis Secundae. Editum a Carolo a Linné. Brunsvigae. 468 pp. http://dx.doi.org/10.5962/bhl.title.555

Marais, W. \& Reilly, J. (1978) Chlorophytum and its related genera (Liliaceae). Kew Bulletin 32: 653-663. http://dx.doi.org/10.2307/4109671 
Meerts, P. \& Bjorå, C.S. (2012) Synopsis of the genus Chlorophytum (Asparagaceae) in Central Africa (Democratic Republic of the Congo, Rwanda, Burundi). Plant Ecology and Evolution 145: 373-409. http://dx.doi.org/10.5091/plecevo.2012.668

Meerts, P. \& Bjorå, C.S. (2012) Synopsis of the genus Chlorophytum (Asparagaceae) in Central Africa (Democratic Republic of the Congo, Rwanda, Burundi). Plant Ecology and Evolution 145: 373-409. http://dx.doi.org/10.5091/plecevo.2012.668

Müller, K. (2005) SeqState-primer design and sequence statistics for phylogenetic DNA data sets. Applied Bioinformatics 4: 65-69. http://dx.doi.org/10.2165/00822942-200504010-00008

Nixon, K.C. (1999-2002) WINCLADA (Beta), v. 0.9.9 Software published by the author, Ithaca, NY. Available from: http://www. cladistics.com (accessed 1 February 2017)

Nordal, I. \& Kativu, S. (1993) New combinations of African species in the genus Chlorophytum (Anthericaceae). Nordic Journal of Botany 13: 59-65 http://dx.doi.org/10.1111/j.1756-1051.1993.tb00016.x

Nordal, I. (1997) Anthericaceae. In: Edwards, S., Sebsebe Demissew \& Hedberg, I. (Eds.) Flora of Ethiopia and Eritrea 7: 90-105. Addis Ababa and Uppsala.

Nordal, I., Eriksen, T.E. \& Fosby, M. (1990) Studies on the generic delimitation of Anthericaceae. Mitteilungen aus dem Institut für Allgemeine Botanik Hamburg 23b: 535-559.

Nordal, I. \& Thulin, M. (1993) Synopsis of Anthericum and Chlorophytum in the Horn of Africa, including the description of nine new species. Nordic Journal of Botany 13: 257-280. http://dx.doi.org/10.1111/j.1756-1051.1993.tb00047.x

Nordal, I., Kativu, S. \& Poulsen, A.D. (1997) Anthericaceae. In: Polhill, R.M. (Ed.) Flora of Tropical East Africa. A.A. Balkema, Rotterdam.

Nordal, I., Sebsebe, D. \& Stabbetorp, O.E. (2001) Endemism in groups of Ethiopian geophytes (“Liliiflorae”). Biologiske Skrifter 54: $247-258$

Nordal, I. \& Sebsebe, D. (2005) Diversity and endemism of the western Ethiopian escarpment: a preliminary comparison with other areas of Africa. In: Friis, I. \& Balslev, H. (Eds.) Plant diversity and complexity patterns: local, regional and global dimensions. Biologiske Skrifter 55: 315-330.

Nordal, I. \& Sebsebe, D. (2010) Aloes and other Lilies of Ethiopia and Eritrea (2nd ed.). Shama Books, Addis Ababa, Ethiopia, 351 pp.

Nylander, J.A.A. (2004) MrModeltest v2. Program distributed by the author, 2nd ed. Uppsala: Evolutionary Biology Centre, Uppsala University.

Obermeyer, A.A. (1969) A revision of the South African species of Anthericum, Chlorophytum and Trachyandra. Bothalia 7: 669-767. http://dx.doi.org/10.4102/abc.v7i4.1679

Oxelman, B., Lidén, M. \& Berglund, D. (1997) Chloroplast rps-16 intron phylogeny of the tribe Sileneae (Caryophyllaceae). Plant Systematic and Evolution 206: 393-410. http://dx.doi.org/10.1007/BF00987959

Poellnitz, K.v. (1943) Zur Kenntnis der Gatung Chlorophytum Ker. Berichte der Deutschen Botanischen Gesellschaft 61: 126-131

Poellnitz, K.v. (1942) Die Anthericum-Arten Deutch-Ost-Afrika. Repertorium Specierum Novarum Regni Vegetabilis. Centralblatt für Sammlung und Veroffentlichung von Einzeldiagnosen neuer Pflanzen 51: 113-139.

Richard, A. (1850) Tentamen florae abyssinicae. Vol 2. A. Bertrand, Paris, 518 pp

Ronquist, F. \& Huelsenbeck, J.P. (2003) MrBayes 3: Bayesian phylogenetic inference under mixed models. Bioinformatics 19: 1572 1574 .

http://dx.doi.org/10.1093/bioinformatics/btg180

Schweinfurth, G. (1867) Beitrag zür Flora Aethiopiens. G. Reimer. Berlin, 311 pp.

Schweinfurth, G. (1876) Revision of the genera and species Anthericeae and Eriospermeae. Journal of the Linnean Society, Botany 15: $253-363$ http://dx.doi.org/10.1111/j.1095-8339.1876.tb00247.x

Sebsebe, D., Nordal, I., Herrmann, C., Friis, I., Tesfaye, A. \& Stabbetorp, O.E. (2005) Diversity and endemism of the western Ethiopian escarpment: a preliminary comparison with other areas of Africa. In: Friis, I. \& Balslev, H. (Eds.) Plant diversity and complexity patterns: local, regional and global dimensions. Biologiske Skrifter 55: 315-330.

Sebsebe, D. \& Nordal, I. (2010) Aloes and other Lilies of Etiopia and Eritrea (2nd ed.). Shama Books, Addis Ababa, 351 pp.

Simmons, M.P. \& Ochoterena, H. (2000) Gaps as characters in sequence-based phylogenetic analyses. Systematic Biology 49: 369-381. http://dx.doi.org/10.1093/sysbio/49.2.369

Taberlet, P., Gielly, L. \& Bouvet, J. (1991) Universal primers for amplification of three non-coding regions of chloroplast DNA. Plant Molecular Biology 17: 1105-1109. 
http://dx.doi.org/10.1007/BF00037152

Tesfaye Awas \& Nordal, I. (2007) Beninshangul Gumuz region in Ethiopia: A center of endemicity for Chlorophytum-with the description of C. pseudocaule sp. nov. (Anthericaceae). Kew Bulletin 62: 129-132.

Thulin, M. (1995) Flora of Somalia, vol. 4. Royal Botanic Gardens, Kew, 298 pp.

Thunberg, C.P. (1794) Prodromus Plantarum Capensis. Edman, Uppsala, 87 pp.

http://dx.doi.org/10.5962/bhl.title.84

White, F. (1983) The vegetation of Africa. A descriptive memoir to accompany the UNESCO/AETFAT/UNSO vegetation map of Africa. Natural Resources Research 20: 1-356. [UNESCO, Paris]

White, T.J., Bruns, T., Lee, S. \& Taylor, J. (1990) Amplification and direct sequencing of fungal ribosomal RNA genes for phylogenetics. In: Innis M.A., Gelfand, D.H., Shinsky, J.J. \& White, T.J. (Eds.) PCR Protocols: A Guide to Methods and Applifications. Academic Press, San Diego, pp 315-322. 